\author{
RenAtA ReTtinger, FRAnCiszek Mróz \\ Uniwersytet Pedagogiczny w Krakowie, Polska • Pedagogical University of Cracow, Poland
}

\title{
Popytowe uwarunkowania rozwoju usług rekreacyjnych w Krakowie na przykładzie młodzieży akademickiej
}

\author{
Demand-related Conditions of the Development of Recreational Services \\ in Krakow Based on the Example of University Students
}

\begin{abstract}
Streszczenie: Rosnące znaczenie rekreacji jako zjawiska gospodarczego budzi pytania dotyczące mechanizmów jej rozwoju. Współcześnie podstawowym regulatorem procesów gospodarczych jest rynek i relacje popyt-podaż. W związku z tym w niniejszym opracowaniu podjęto próbę określenia czynników warunkujących wielkość i strukturę popytu na usługi rekreacyjne młodzieży akademickiej Krakowa. Badaniami ankietowymi objęto w sumie 490 studentów studiów stacjonarnych i niestacjonarnych pierwszego stopnia Uniwersytetu Pedagogicznego w Krakowie, Uniwersytetu Papieskiego Jana Pawła II oraz Uniwersytetu Rolniczego. Jedną z hipotez badawczych była weryfikacja stwierdzenia, że czynnik ekonomiczny leży u podstaw możliwości uczestniczenia w rekreacji. Współcześnie młodzi ludzie mają wiele możliwości aktywnego wypoczynku i rekreacji. Czy zatem wydaje się zasadne stwierdzenie, że jedynie czynnik ekonomiczny może utrudniać uczestnictwo w różnych formach rekreacji? Badania wykazały, że główną barierą ograniczającą uczestnictwo studentów w różnych formach rekreacji jest brak wolnego czasu (34\% ogółu odpowiedzi), następnie sytuacja finansowa $(20,73 \%)$ oraz „brak chęci” (16,16\% wszystkich wskazań). Blisko połowa respondentów $(46,6 \%)$ wskazała, że przynajmniej raz w tygodniu korzysta z bazy sportowo-rekreacyjnej Krakowa, przy czym 5,9\% codziennie, 24,5\% - dwa-trzy razy w tygodniu, zaś 16,2\% - raz w tygodniu. Porównanie wyników badań prowadzi do wniosku, że studenci dysponują wolnym czasem, ale przeznaczają go na korzystanie z internetu, natomiast aktywny wypoczynek i rekreacja są zajęciami o mniejszym znaczeniu.
\end{abstract}

\footnotetext{
Abstract: The growing importance of recreation as an economic phenomenon raises questions on its developmental mechanisms. At present, the market and demand-supply relations are the basic regulators of economic processes. Therefore, this paper is an attempt to determine the factors which are conditions for the size and structure of demand for recreation services among the university students in Krakow. The survey was administered among a total of 490 students of full-time and extramural undergraduate studies at the Pedagogical University in Krakow, the Pontifical University of John Paul II and the Agricultural University. One of the research hypotheses was the verification of the statement that the economic factor lies at the base of the possibilities to participate in recreation. Currently, young people have broad possibilities of active relaxation and recreation and it seems justified to state that only an economic factor may hinder participation in various forms of recreation. Research has shown that the main barriers that restrict student participation in various forms of recreation include the lack of free time (34\% of all answers), followed by the financial condition $(20.73 \%)$ and "lack of eagerness" (16.16\%). Almost half of the respondents (46.6\%) indicated that they use sports and recreational facilities in Krakow at least once a week while $5.9 \%$ do it every day, $24.5 \%$ twice or three times a week, $16.2 \%$ once a week. The comparison of research results leads to the conclusion that students have their free time but they spend it on the Internet whereas active relaxation and recreation are of less importance to them.
} 
Słowa kluczowe: aktywność turystyczna; czas wolny; funkcja rekreacyjna; turystyka; usługi rekreacyjne

Keywords: free time; recreation function; recreation services; tourism; tourism activity

Otrzymano: 21 stycznia 2016

Received: 21 January 2016

Zaakceptowano: 20 lipca 2016

Accepted: 20 July 2016

Sugerowana cytacja / Suggested citation:

Rettinger, R., Mróz, F. (2016). Popytowe uwarunkowania rozwoju usług rekreacyjnych w Krakowie na przykładzie młodzieży akademickiej, Prace Komisji Geografii Przemysłu Polskiego Towarzystwa Geograficznego, 30(4), 158-173.

\section{WSTĘP}

Potrzeba wypoczynku i regeneracji sił jest aktualnie jednym z ważniejszych elementów składowych stylu życia współczesnych mieszkańców dużych miast. Miasta oraz ich otoczenie stwarzają wiele możliwości aktywnego wypoczynku, są tam zarówno obszary rekreacyjne na „świeżym powietrzu”, jak i obiekty o przeznaczeniu rekreacyjnym i rozrywkowym. Zmiana zachowań rekreacyjnych mieszkańców miast ma wpływ na wielkość zaplecza sportowo-rekreacyjnego oraz różnorodność oferowanych usług. Wydaje się zasadne stwierdzenie, że rynek usług rekreacyjnych w miastach jest bardzo dobrze przygotowany na zwiększający się popyt w zakresie aktywnego wypoczynku.

W niniejszym opracowaniu podjęto próbę analizy uwarunkowań wielkości popytu na usługi rekreacyjne wśród studentów trzech krakowskich uczelni: Uniwersytetu Papieskiego Jana Pawła II w Krakowie, Uniwersytetu Pedagogicznego im. Komisji Edukacji Narodowej w Krakowie oraz Uniwersytetu Rolniczego im. Hugona Kołłątaja w Krakowie. W badaniach wykorzystano kwestionariusz ankiety skonstruowany przez autorów prezentacji, który zawierał 32 pytania dotyczące funkcji rekreacyjnej miasta, znaczenia urządzeń rekreacyjno-sportowych $\mathrm{w}$ rozwoju tej funkcji, kultury wolnego czasu oraz zdrowego trybu życia. Opracowanie jest próbą analizy wielkości i struktury popytu na usługi rekreacyjne w Krakowie w obrębie jednej grupy (studenci).

\section{METODYKA BADAŃ}

Bazę empiryczną opracowania stanowiły wyniki badań ankietowych przeprowadzonych na reprezentatywnej grupie studentów w trzech krakowskich uczelniach: w Uniwersytecie Papieskim Jana Pawła II, Uniwersytecie Pedagogicznym oraz Uniwersytecie Rolniczym. Jednym z podstawowych warunków przeprowadzonych badań był udział w nich minimum 60\% studentów danego kierunku. Założenie to zostało spełnione, gdyż próba w przypadku wszystkich uczelni wyniosła ponad 70\% ogółu studiujących.

W badaniach wykorzystano arkusz ankiety skonstruowany przez autorów prezentowanego opracowania, który składał się z trzech części: krótkiej informacji o celu 
badań, zestawu 32 pytań oraz metryczki. Pytania zamknięte zarówno z odpowiedziami ilościowymi, jak i kategorialnymi (kafeteria dysjunktywna i koniunktywna) dotyczyły: funkcji rekreacyjnej miasta, znaczenia urządzeń rekreacyjno-sportowych w rozwoju tej funkcji, spędzania wolnego czasu, uprawiania turystyki, czynników hamujących aktywność turystyczną, tradycji rodzinnych w uprawianiu turystyki.

Badania pilotażowe zostały przeprowadzone w grudniu 2014 roku, a ich głównym celem była weryfikacja przygotowanej ankiety. Właściwe badania ankietowe - audytoryjne, przeprowadzono w dwóch okresach: od stycznia do czerwca 2015 roku wśród studentów studiów stacjonarnych i niestacjonarnych, a także od października do grudnia 2015 roku wśród studentów I roku studiów stacjonarnych rozpoczynających studia w roku akademickim 2015/2016.

Zgromadzone podczas badań materiały zostały uporządkowane i opracowane statystycznie $\mathrm{w}$ formie graficznej oraz $\mathrm{w}$ formie tablic wynikowych. Wykorzystano tu m.in. metody prezentacji graficznej. W przedstawieniu wyników posłużono się przede wszystkim metodą opisowo-analityczną oraz dynamiczno-porównawczą. Autorzy prezentowanego tekstu pragną podkreślić, że przeprowadzone badania mają charakter przyczynkowy i są podstawą do szerszych badań związanych z aktywnością turystyczną, czasem wolnym i zdrowym trybem życia dzieci, młodzieży oraz studentów w wybranych regionach Polski.

\section{ChARAKTERYSTYKA BADANEJ GRUPY}

Badania związane z kulturą czasu wolnego oraz aktywnością turystyczną wśród studentów są prowadzone od kilkunastu lat i dotyczą różnych ośrodków akademickich w Polsce, m.in.: Krakowa i Jarosławia (Delekta, 2013; 2014), Poznania (Bergier, 2012), Łodzi (Latosińska, Ludwicka, 2010), Torunia (Lubowiecki-Vikuk, Podgórski, 2013), Rzeszowa (Godek, Brożyna, Śliż, 2014), Słupska (Zaniewska, 2012), Kielc (Kamińska, 2009).

Badaniami ankietowymi objęto w sumie 490 studentów I, II i III roku studiów stacjonarnych i niestacjonarnych pierwszego stopnia, przy czym na Uniwersytecie Pedagogicznym przebadano w sumie 375 studentów kierunku turystyka i rekreacja, na Uniwersytecie Papieskim Jana Pawła II w Krakowie 24 studentów I i II roku studiów stacjonarnych na kierunku turystyka religijna, a w Uniwersytecie Rolniczym w Krakowie badania ankietowe przeprowadzono w grupie 91 studentów kierunku ekonomia. Ponad $80 \%$ ogółu badanych (81,24\%) stanowiły kobiety, 18,76\% mężczyźni, przy czym odsetek kobiet wśród studentów Uniwersytetu Rolniczego (82,22\%) i Uniwersytetu Pedagogicznego $(81,4 \%)$ był wyższy od studentów Uniwersytetu Papieskiego $(75 \%)$. Ponad 96\% respondentów była w wieku 19-24 lat, a tylko 16 osób miało powyżej 25 lat (10 studentów było w wieku 25-29 lat, cztery osoby w wieku 30-34 lat i dwie osoby powyżej 50 lat). Ponad $2 / 3$ ankietowanych $(67,3 \%$ ) zamieszkiwało województwo małopolskie, z czego grupa 162 studentów (33\%) mieszkała w Krakowie. Poza Małopolską najwięcej osób mieszkało w województwie śląskim (6,7\%), podkarpackim $(5,5 \%)$ i świętokrzyskim (4,5\%). Ponad 11\% badanych nie wskazało miejsca zamieszkania. 


\section{USŁUGI REKREACYJNE W MIEŚCIE}

Przemiany polityczne, a przede wszystkim gospodarcze ostatnich lat (gospodarka wolnorynkowa) zasadniczo zmieniły politykę zarządzania terenami w miastach. Przestrzeń miejska uległa znacznej komercjalizacji, a przestrzeń wolna, niezabudowana stała się deficytowa. Zmiany te wpłynęły również na system terenów rekreacyjnych w miastach, które często składają się z terenów otwartych, spontanicznie wykorzystywanych w celach wypoczynkowych (Maksymiuk, 2005). Z powodu deficytu przestrzeni można zaobserwować zabudowywanie terenów otwartych w dużych miastach, szczególnie w atrakcyjnych dzielnicach. Jest paradoksem, że największą popularnością cieszą się nieruchomości położone w sąsiedztwie dużych, otwartych terenów rekreacyjnych, ale bardzo często wybudowanych kosztem zmniejszenia areału obszarów zielonych.

Ta dostępność obszarów rekreacyjnych często jest stawiana na równi z innymi aspektami, takimi jak np. dogodna komunikacja, które brane są pod uwagę przy kupnie nieruchomości. W obrębie wielu miast znajduje się nadal dość dużo niezagospodarowanych terenów otwartych, które są spontanicznie wykorzystywane w celach rekreacyjnych, aczkolwiek coraz więcej mieszkańców nie akceptuje tego typu terenów jako obszarów wypoczynkowych, gdyż nie są one do tego celu przystosowane ani odpowiednio urządzone. Jest to dowód na to, że w porównaniu do lat ubiegłych wymagania mieszkańców rosną (Maksymiuk, 2005). Ostatnie lata oznaczają zmianę poglądów na pojęcie rekreacji. Wcześniej była ona postrzegana jako wypoczynek „na świeżym powietrzu”, „na łonie przyrody”, aktualnie rekreacja jest łączona z rozrywką i może mieć miejsce w różnych obiektach.

Współczesne miasto posiada różnorodne miejsca aktywności społecznej, w których przestrzenie rekreacyjne stanowią specyficzną i atrakcyjną formę. Obszary i obiekty rekreacyjne są obecne w strukturze przestrzenno-funkcjonalnej każdego miasta, choć w różnej skali. Ostatnie lata oznaczają dla polskich miast okres intensywnego rozwoju infrastruktury służącej aktywnej rekreacji (Ujma-Wąsowicz, 2007). W ramach tych działań powstają m.in.: nowocześnie wyposażone hale sportowe, kryte pływalnie, boiska wielofunkcyjne, skateparki. W ramach procesu rewitalizacji niektórych części miast adaptowane są istniejące budynki czy też pomieszczenia na kręgielnie, siłownie, sale bilardowe, sale do sztuk i sportów walki. Na terenach bezpośrednio sąsiadujących z miastami powstaje infrastruktura dla sportów plenerowych, czyli korty do tenisa ziemnego, boiska do siatkówki plażowej i piłki nożnej. Dawniej funkcję rekreacyjną przypisywano przede wszystkim terenom otwartym, zielonym, natomiast obecnie bardzo dużą popularnością cieszą się wyspecjalizowane obiekty rekreacyjne. Elementy infrastruktury rekreacyjnej najogólniej możemy podzielić na kubaturowe i otwarte.

Współczesne życie nacechowane jest znacznym przyspieszeniem, ponownie cenna staje się oszczędność czasu związana z realizowaniem podstawowych funkcji lokalnie (Stangel, 2013). W związku z tym zorganizowana przestrzeń miejska jest skoncentrowaną, wielofunkcyjną strukturą, w której niezbędne funkcje są łatwiej dostępne. Dotyczy to także funkcji rekreacyjnej miast, aktualnie obserwuje się tendencję do lokalizowania nowych komercyjnych obiektów rekreacyjnych w pobliżu biurowców, uczelni, centrów handlowych i dużych osiedli mieszkaniowych. Czynnik dostępności jest 
aktualnie jednym z najważniejszych warunków udanej lokalizacji. Mieszkańcy miast jako wymarzone miejsce rekreacji podają park wyposażony w urządzenia do aktywnego wypoczynku, zlokalizowany w odległości kilku minut od miejsca zamieszkania.

Drugim w kolejności preferowanym miejscem rekreacji są obiekty o charakterze rekreacyjno-rozrywkowym (kina, kręgielnie, kluby), których dostępność komunikacyjna może być już trudniejsza (Maksymiuk, 2005). Mieszkańcy wysoko cenią „zielone” dzielnice miast, gdzie dostęp do terenów rekreacyjnych jest swobodny. Wzrastająca popularność sportów aktywnych wymaga odpowiednio przystosowanych terenów.

Zmiana zachowań wolnoczasowych mieszkańców dużych miast spowodowała zmiany w podaży usług rekreacyjnych. Wiele nowych podmiotów gospodarczych zainwestowało środki w budowę i modernizację obiektów rekreacyjnych (siłownie i kluby fitnessu), które w ostatnich latach cieszą się bardzo dużą popularnością. Należy pamiętać, że bogata oferta podmiotów gospodarczych działających w sferze usług rekreacyjnych jest nastawiona na działalność komercyjną. Ten fakt ma duże znaczenie w kontekście ponoszenia przez mieszkańców miast określonych nakładów związanych z organizacją czasu wolnego. Dawniej podejmowanie działań rekreacyjnych było bezkosztowe. Jedną z hipotez badawczych poniższego opracowania jest pytanie, w jakim stopniu posiadane środki finansowe wpływają na poziom aktywności w czasie wolnym.

\section{KULTURA CZASU WOLNEGO}

Zagadnienie dotyczące sposobów spędzania czasu wolnego może być analizowane w szerokim kontekście społecznym. Badanie preferowanych sposobów spędzania czasu wolnego przez młodzież akademicką jest uzasadnione tym, że procesy zachodzące wśród młodzieży mają charakter symptomatyczny dla szerszych zjawisk społecznych. Sposób spędzania czasu wolnego jest jednym z elementów funkcjonowania, jest odbiciem postaw, zainteresowań i wartości ważnych dla człowieka (Zaniewska, 2012). Młodzież akademicka powinna upowszechniać nowe, aktywne sposoby spędzania czasu wolnego, natomiast badania wskazują sytuację odwrotną. Coraz częściej mamy do czynienia z „wyuczoną bezczynnością", czyli brakiem umiejętności konstruktywnego spędzania czasu wolnego (Zaniewska, 2012).

Wyniki przeprowadzonych badań skłaniają do wielu analiz socjologiczno-społecznych, choć zapewne nie dziwią już tak bardzo badaczy zajmujących się zagadnieniem czasu wolnego młodzieży. Interesująco przedstawiają się odpowiedzi na pierwsze pytanie: „W jaki sposób najczęściej spędza Pan/i czas wolny?”, na które respondenci mogli udzielić maksymalnie trzech odpowiedzi z siedmiu wskazanych w ankiecie. Pewnym zaskoczeniem może być fakt, że najczęściej wskazywaną przez respondentów formą spędzenia wolnego czasu są spotkania z przyjaciółmi - kolegami (niemal 29,4\% ogółu odpowiedzi) (ryc. 1). Drugim najczęściej wskazywanym zajęciem realizowanym w wolnym czasieprzez badaną grupę studentów jest słuchanie muzyki (18,4\%), zaś w dalszej kolejności uprawianie sportu $(14,2 \%)$ oraz czas spędzony przy komputerze lub konsoli (13,3\%) (ryc. 1). W odniesieniu do tej ostatniej odpowiedzi zapytano studentów, ile czasu w ciągu doby poświęcają na przeglądanie stron internetowych (w tym także 
portali społecznościowych np. Facebook, Twitter), oglądanie telewizji, filmów, seriali telewizyjnych, czy w końcu na gry komputerowe lub gry na konsolach.

Ryc. 1. Formy spędzania wolnego czasu przez badaną grupę respondentów

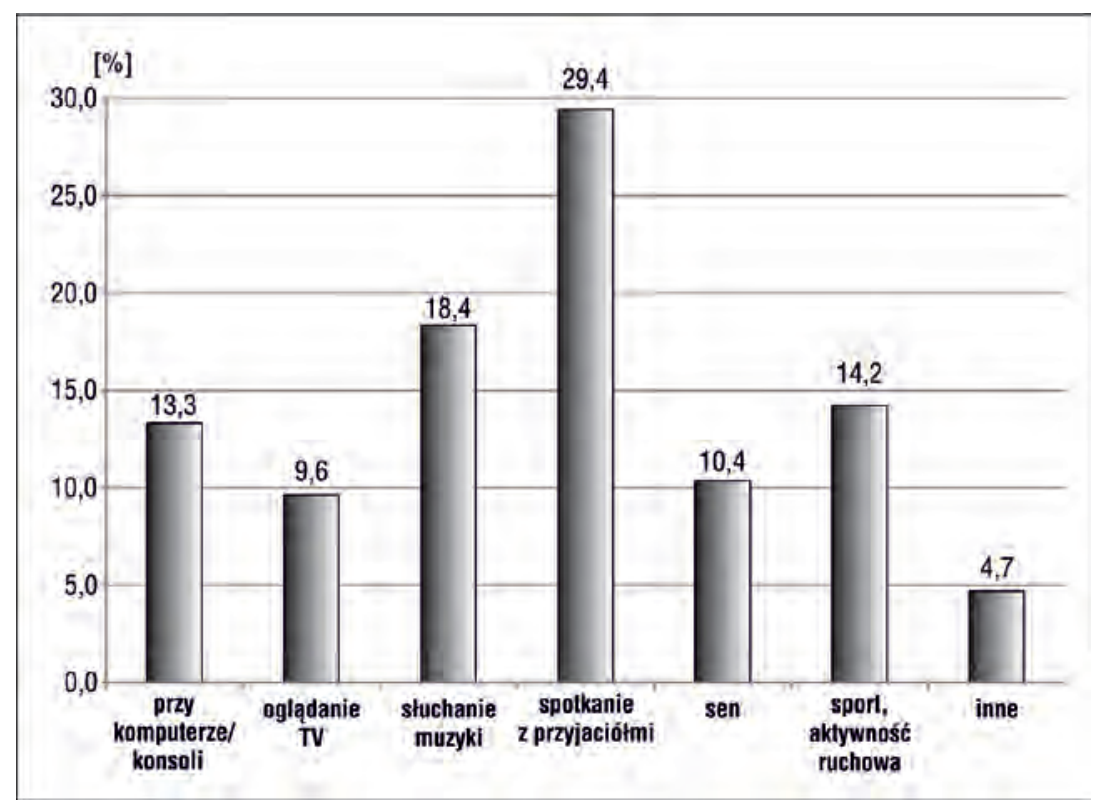

Źródło: opracowanie własne na podstawie przeprowadzonych badań

W doniesieniach medialnych podawane są dane, z których wynika, iż przeciętni nastolatkowie spędzają w sieci średnio 3 godziny i 40 minut. Aktualne badania prowadzone w wielu ośrodkach akademickich wskazują, że obecnie internet stał się najważniejszym medium dla młodzieży. Wręcz mówi się o „zarazie informatycznej”, którą można dostrzec w organizacji czasu wolnego (Czerepniak-Walczak, 2007).

Ponad 43\% respondentów wskazała, że każdego dnia spędza co najmniej 2 godziny, przeglądając strony internetowe, a 10,6\% ogółu badanych podało, że codziennie w internetowym świecie spędza ponad 4 godziny (ryc. 2). Tylko czterech respondentów zadeklarowało, że nie przegląda stron internetowych.

Porównując wyniki przeprowadzonych badań dotyczących czasu spędzonego na przeglądanie stron internetowych (w tym także portali społecznościowych, np. Facebook, Twitter) wśród studentów badanych ośrodków akademickich, należy podkreślić, że studenci Uniwersytetu Rolniczego oraz Uniwersytetu Papieskiego w Krakowie znacznie krócej surfują po internecie w porównaniu do kolegów i koleżanek z Uniwersytetu Pedagogicznego. Warto zwrócić bowiem uwagę, że 27,8\% badanej grupy studentów Uniwersytetu Rolniczego i 33,4\% Uniwersytetu Papieskiego każdego dnia spędza ponad 2 godziny w wirtualnym świecie, zaś w przypadku studentów Uniwersytetu Pedagogicznego było to 47,5\% ogółu badanych. 
Ryc. 2. Czas (średnia w ciągu doby) spędzany na przeglądaniu stron internetowych (w tym także portali społecznościowych) przez badaną grupę respondentów

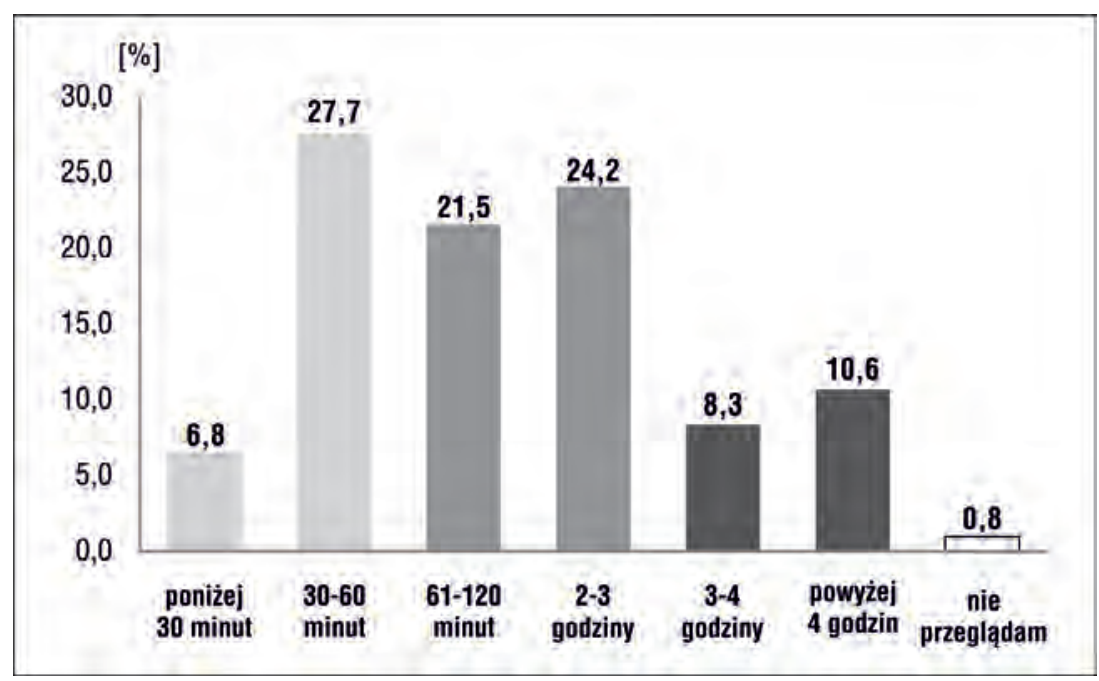

Źródło: opracowanie własne na podstawie przeprowadzonych badań

Ryc. 3. Czas (średnia w ciągu doby) spędzany na oglądaniu telewizji, filmów lub seriali filmowych w ciągu doby przez badaną grupę respondentów

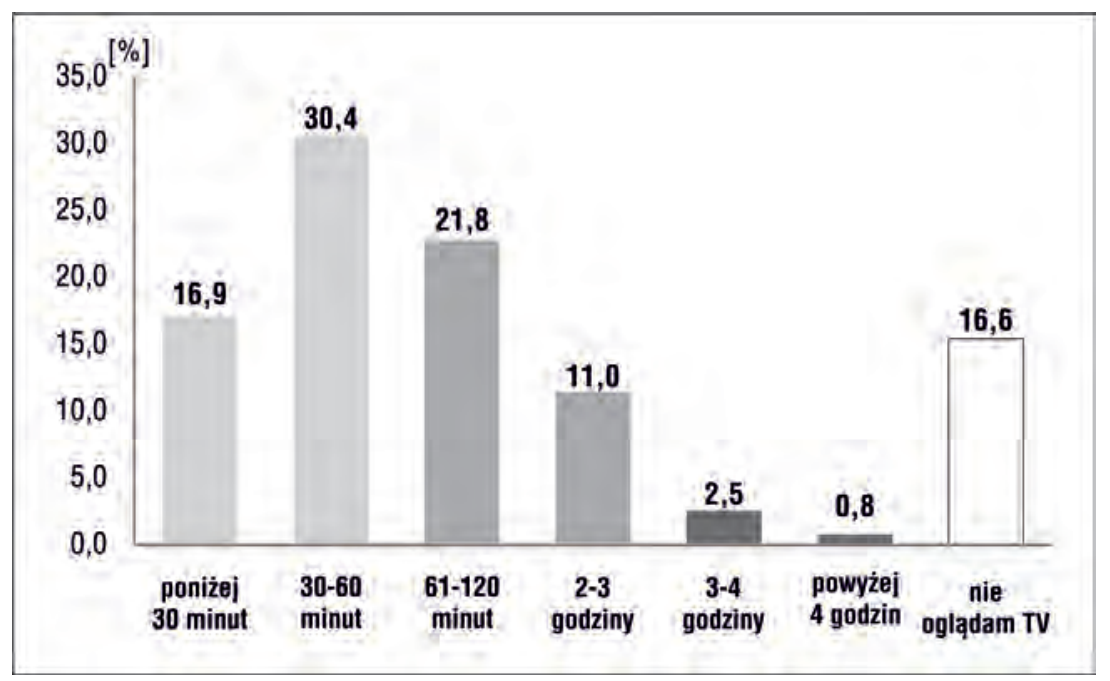

Źródło: opracowanie własne na podstawie przeprowadzonych badań

Odmiennie przedstawiają się rozkłady odpowiedzi na pytania dotyczące długości czasu spędzanego na oglądaniu telewizji (programów, filmów, seriali telewizyjnych) oraz na gry komputerowe lub gry na konsolach. Ponad 16\% respondentów zadeklarowała, że nie ogląda telewizji, a blisko połowa badanych $(47,3 \%)$ spędza przed telewizorem nie dłużej niż godzinę w ciągu doby. Grupa respondentów, którzy każdego 
dnia spędzają na oglądaniu telewizji ponad 2-3 godziny, stanowi 14,3\% ogółu (ryc. 3). Studenci Uniwersytetu Papieskiego Jana Pawła II w Krakowie znacznie rzadziej oglądają telewizję (25\% nie ogląda jej wcale) w porównaniu ze studentami Uniwersytetu Pedagogicznego w Krakowie i Uniwersytetu Rolniczego w Krakowie.

Nieco zaskakujące wydawać się mogą wyniki dotyczące czasu przeznaczonego na gry komputerowe lub gry na konsolach wśród badanej grupy studentów. Brak zainteresowania taką rozrywka zadeklarowała ponad $72 \%$ badanych. Odsetek respondentów, którzy każdego dnia ponad 2 godziny grają na komputerze, jest niewielki i wynosi niespełna 4\% (ryc. 4).

Ryc. 4. Czas (średnia w ciągu doby) spędzany na grach komputerowych lub grach na konsolach przez badaną grupę respondentów

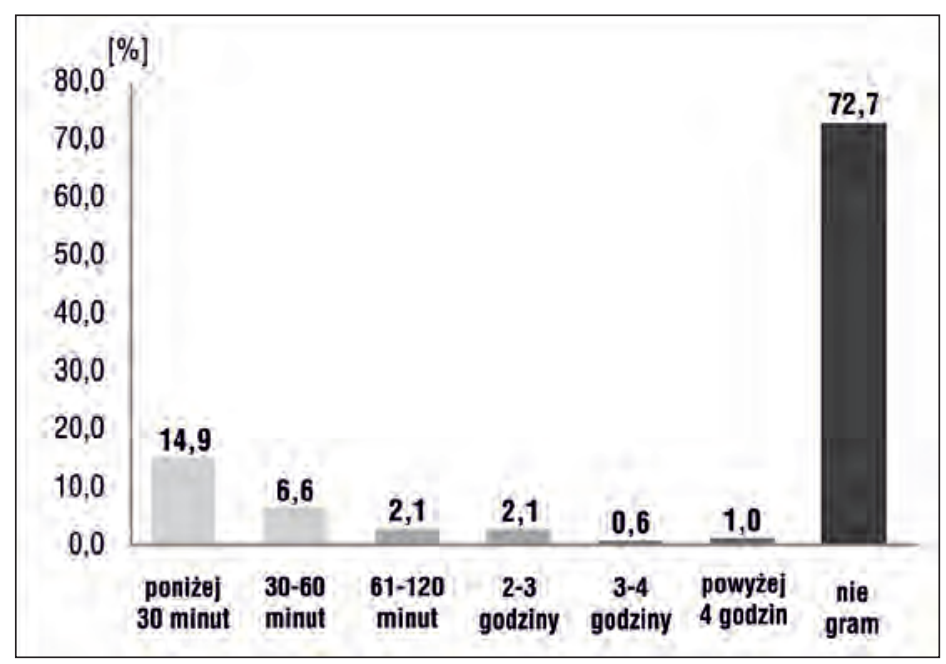

Źródło: opracowanie własne na podstawie przeprowadzonych badań

Z przedstawionego $\mathrm{w}$ tab. 1 rozkładu odpowiedzi na pytanie „Ile w ciągu ostatniego roku odbył/a Pan/i wyjazdów turystycznych (z wyłączeniem obligatoryjnych wyjazdów na studiach)?" wynika, że tylko 11 respondentów (2,24\%) (z których 10 to studenci Uniwersytetu Rolniczego, czyli 11\% ogółu respondentów tej uczelni) odpowiedziało, że nie wyjechało $\mathrm{w}$ celach turystycznych w ostatnim roku (roku poprzedzającym przeprowadzone badanie). Największą grupę wśród badanych stanowili studenci, którzy w ciągu ostatniego roku wyjeżdżali trzykrotnie $(22,65 \%)$ i dwukrotnie $(21,43 \%)$. Na podkreślenie zasługuje jednak także grupa 79 badanych (16,12\%), która wskazała, że podróżowała w ostatnim roku więcej niż sześć razy. Porównując częstotliwość wyjazdów turystycznych wśród studentów badanych ośrodków akademickich, widać wyraźnie, że studenci kierunku turystyka i rekreacja na Uniwersytecie Pedagogicznym w Krakowie podróżują częściej niż studenci Uniwersytetu Papieskiego Jana Pawła II oraz studenci Uniwersytetu Rolniczego. Ponad 30\% studentów Instytutu Geografii Uniwersytetu Pedagogicznego wskazało, że w ostatnim roku wyjeżdżało w celach turystycznych co najmniej pięć razy w ostatnim roku, zaś w przypadku studentów było to zaledwie 13,19\% Uniwersytetu Rolniczego, a 20,83\% Uniwersytetu Papieskiego (por. tab. 1). 
Tab. 1. Częstotliwość wyjazdów turystycznych w ostatnim roku studentów kierunku turystyka i rekreacja wybranych ośrodków akademickich w Krakowie - rozkład odpowiedzi na pytanie: „Ile w ciągu ostatniego roku odbył/a Pan/i wyjazdów turystycznych?"

\begin{tabular}{|l|c|c|c|c|c|c|c|c|c|}
\hline \multirow{2}{*}{$\begin{array}{l}\text { Ośrodek } \\
\text { akademicki }\end{array}$} & Wcale & 1 & 2 & 3 & 4 & 5 & $6-10$ & $\begin{array}{c}\text { Powyżej } \\
10\end{array}$ & $\begin{array}{c}\text { Brak } \\
\text { odpowiedzi }\end{array}$ \\
\cline { 2 - 10 } & $\%$ & $\%$ & $\%$ & $\%$ & $\%$ & $\%$ & $\%$ & $\%$ & $\%$ \\
\hline $\begin{array}{l}\text { Uniwersytet } \\
\text { Papieski } \\
\text { w Krakowie }\end{array}$ & 0 & 25,0 & 20,83 & 20,83 & 12,50 & 8,33 & 4,17 & 8,33 & 0,0 \\
\hline $\begin{array}{l}\text { Uniwersytet } \\
\text { Pedagogiczny } \\
\text { w Krakowie }\end{array}$ & 0,27 & 10,13 & 18,67 & 23,47 & 15,73 & 12,0 & 12,27 & 6,67 & 0,8 \\
\hline $\begin{array}{l}\text { Uniwersytet } \\
\text { Rolniczy } \\
\text { w Krakowie }\end{array}$ & 10,99 & 12,09 & 32,97 & 19,78 & 8,79 & 7,69 & 4,40 & 1,10 & 2,20 \\
\hline Ogółem & 2,24 & 11,22 & 21,43 & 22,65 & 14,29 & 11,02 & 10,41 & 5,71 & 1,02 \\
\hline
\end{tabular}

Źródło: opracowanie własne na podstawie przeprowadzonych badań

\section{INHIBITORY AKTYWNOŚCI TURYSTYCZNEJ I REKREACYJNEJ}

Przeprowadzone badania miały na celu również poznanie, jakie czynniki warunkują aktywność rekreacyjną studentów. W opracowaniu wykorzystano termin „inhibitor” aktywności turystycznej i rekreacyjnej, którego twórcą jest W. Alejziak, i za tym autorem rozumiany jest on jako „czynnik hamujący proces tworzenia się i podejmowania aktywności turystycznej, prowadząc w danym momencie do braku wyjazdu, choć nie wykluczając podjęcia tej aktywności w przyszłości” (Alejziak, 2007). Na potrzeby niniejszego opracowania użyto tego terminu także w kontekście aktywności wolnoczasowej - rekreacyjnej.

Formułując pytania dotyczące głównych przeszkód w podejmowaniu aktywności turystycznej, kierowano się przyjętą w literaturze przedmiotu typologią opracowaną przez Ch.R. Goeldnera i B.J. Ritchie, którzy wyróżnili sześć głównych barier w podróżowaniu: brak czasu, koszty, ograniczenia zdrowotne, czynniki rodzinne, obawa o bezpieczeństwo i brak zainteresowania. Jakie zatem są główne inhibitory aktywności turystycznej badanej grupy studentów kierunku turystyka i rekreacja? Na zadane pytanie: „Jakie są według Pana/i główne bariery podejmowania przez Pana/Panią aktywności turystycznej?" studenci mogli zaznaczyć maksymalnie trzy z dziewięciu zaproponowanych odpowiedzi (Mróz, Rettinger, 2015).

Przeprowadzone badania ankietowe wykazały, że największą barierą w aktywności turystycznej badanych studentów jest brak wolnego czasu (34\% ogółu odpowiedzi), następnie sytuacja finansowa (20,73\%) oraz brak chęci (16,16\% wszystkich wskazań). Do pozostałych przeszkód należą praca zawodowa (9,15\% wskazań) i sytuacja rodzinna $(2,44 \%)$. Należy podkreślić, że 13,72\% wskazań respondentów dotyczyło braku barier w podejmowaniu aktywności turystycznej. Warto zwrócić uwagę, że głosy studentów za wyjątkiem odpowiedzi „nie dostrzegam barier” i problemów zdrowotnych rozłożyły się bardzo podobnie (ryc. 5). 
Ryc. 5. Inhibitory aktywności turystycznej badanej grupy studentów

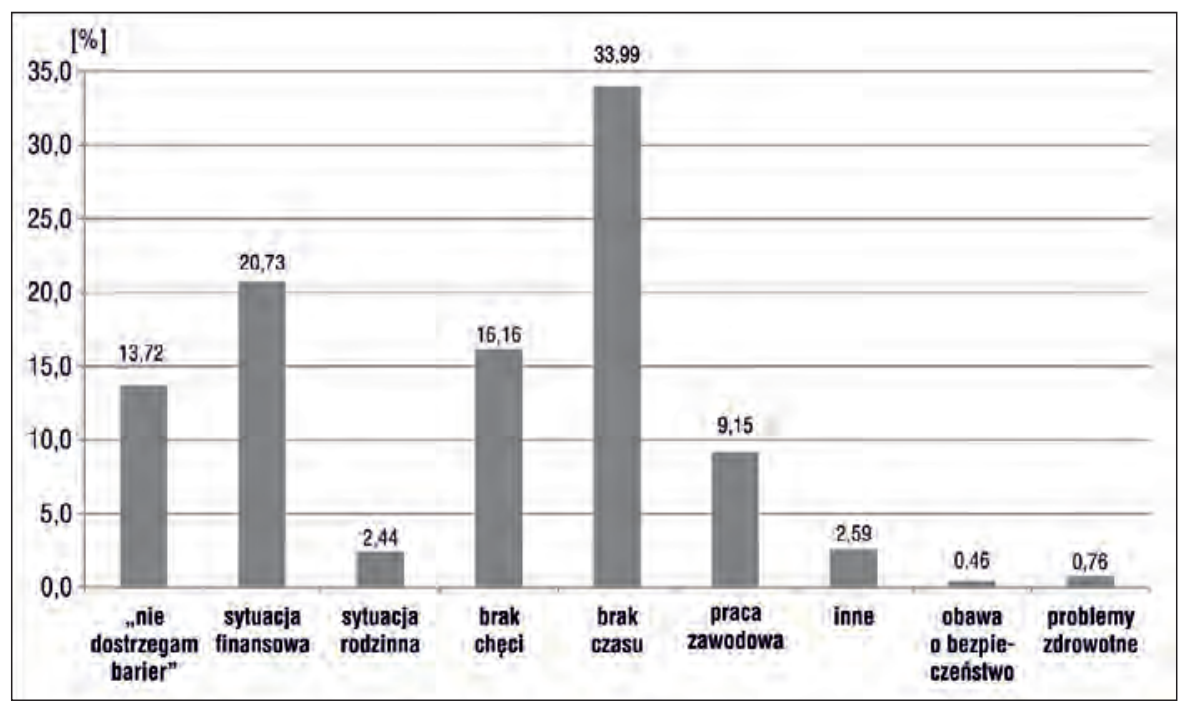

Źródło: opracowanie własne na podstawie przeprowadzonych badań

Problem braku wolnego czasu jest jednym z najczęściej wymienianych inhibitorów aktywności turystycznej czy też ruchowej (Bergier, 2012). W opozycji do tego stwierdzenia stoją badania Flash Eurobarometr (2007), według których niemal we wszystkich krajach UE czas wolny ludzi młodych w wieku 15-19 lat stanowi 20\% ich całkowitego budżetu czasu. Po przekroczeniu 30 roku życia ulega on znacznemu obniżeniu (mniej więcej o jedną czwartą), co wynika z nagłego zwiększenia obowiązków domowych i rodzinnych. W związku z tym pojawia się zagadnienie spędzania wolnego czasu, a w szczególności mediatyzacja życia kulturalnego i czasu wolnego młodzieży akademickiej, co zostanie poruszone w kolejnej części opracowania.

W dotychczasowej literaturze przedmiotu bardzo często za główną barierę aktywności turystycznej uznawano czynnik ekonomiczny. Przeprowadzone badania wskazują, że jego znaczenie jest mniejsze, co wynika z ogólnych trendów rozwojowych społeczeństwa polskiego. W ostatnich latach materialne warunki życia społecznego uległy poprawie, czego konsekwencją jest poszerzenie się możliwości aktywnego wykorzystania czasu wolnego, zatem czas wolny może być istotną kategorią wyjaśniającą zmiany społeczne, również w ujęciu globalnym (Lubowiecki-Vikuk, Paczyńska-Jędrycka, 2010; Zielińska, 2011).

\section{ROZWÓJ USŁUG REKREACYJNYCH KRAKOWA}

Współczesne zmiany modelu zachowań wolnoczasowych spowodowały powstanie i rozwój rożnych obiektów, w których są świadczone usługi rekreacyjne. Model spontanicznego wykorzystywania przestrzeni niezabudowanych i otwartych obiektów sportowych (boiska osiedlowe i szkolne) w celach rekreacyjnych ustąpił miejsca wyspecjalizowanym i dobrze wyposażonym obiektom rekreacyjnym (siłownie, kluby fitness). Szczególnie dotyczy to dużych miast, w których ciągle powstają nowe obiekty. 
Ponad 85\% respondentów uważa, że powstanie i rozbudowa infrastruktury sportowo-rekreacyjnej Krakowa jest istotnym czynnikiem motywującym aktywność ruchową, 8\% badanych nie ma w tej kwestii wypracowanego zdania, a jedynie 5\% uważa, że nie ma to znaczenia. Interesująco przedstawia się rozkład odpowiedzi na pytanie „Jak często korzysta Pan/i z urządzeń sportowo-rekreacyjnych Krakowa?”. Blisko połowa respondentów $(46,6 \%)$ wskazała, że przynajmniej raz w tygodniu korzysta z bazy sportowo-rekreacyjnej Krakowa, przy czym 5,9\% codziennie, 24,5\% - dwa-trzy razy w tygodniu, zaś $16,2 \%$ - raz w tygodniu. Niemal $20 \%$ badanych wskazało, że bardzo rzadko (kilka razy w roku) korzysta z analizowanej bazy, zaś 14,2\% ankietowanych nie korzysta z niej wcale (ryc. 6).

Ryc. 6. Częstotliwość korzystania z obiektów i urządzeń sportowo-rekreacyjnych Krakowa przez badaną grupę respondentów

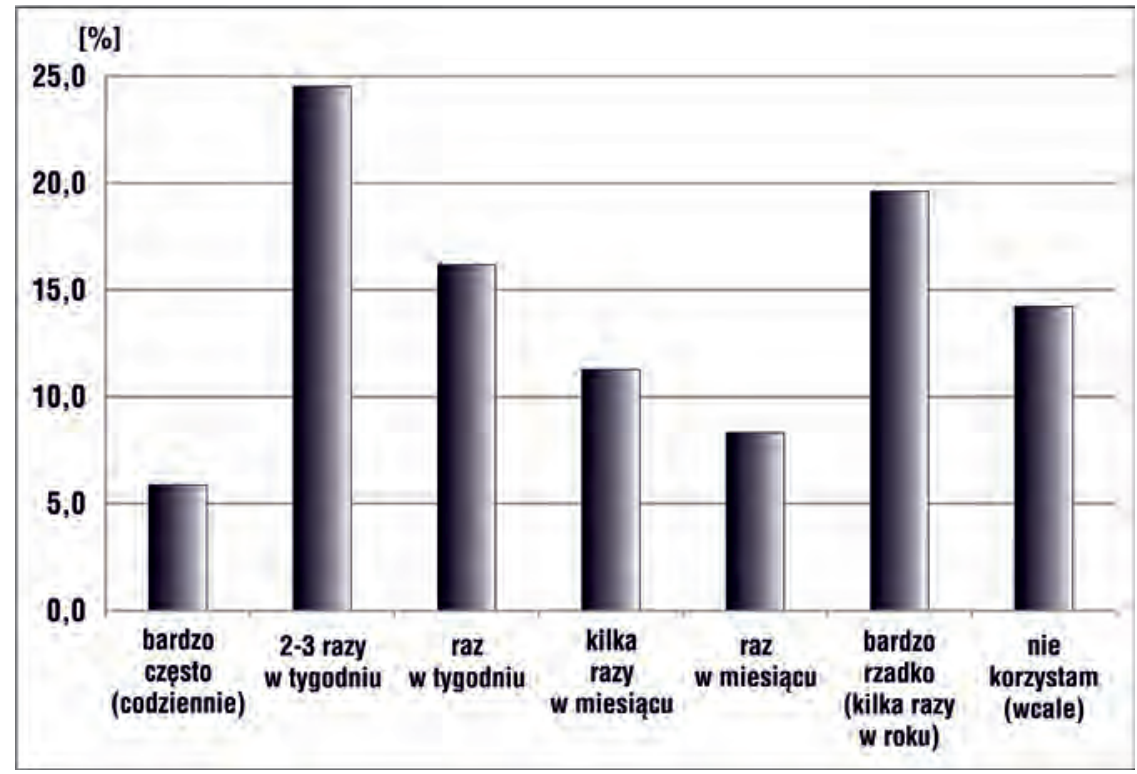

Źródło: opracowanie własne na podstawie przeprowadzonych badań

Jednym z celów przeprowadzonych badań było uzyskanie odpowiedzi na pytanie, jakie obiekty - urządzenia mają największe znaczenie w rozwoju funkcji rekreacyjnej miasta. Respondenci mieli możliwość wskazania maksymalnie trzech odpowiedzi z 11 zaproponowanych. Do obiektów i urządzeń, które wśród badanej grupy studentów mają największy udział w rozwoju omawianej funkcji, należą: baseny $(18,7 \%$ wszystkich wskazań), siłownie $(18,2 \%)$, ścieżki rowerowe $(16,9 \%)$, boiska do gier zespołowych $(15,2 \%)$ oraz kluby fitness $(13,5 \%$ ogółu odpowiedzi). Z kolei najmniejszą rangę studenci przypisali szlakom nordic-walking (1,3\% odpowiedzi), ściankom-wspinaczkowym (2,2\%) oraz kręgielniom (2,7) (ryc. 7). Szczegółowa analiza wskazań studentów badanych ośrodków akademickich wykazała pewne zróżnicowanie w określeniu znaczenia obiektów i urządzeń rekreacyjnych w rozwoju funkcji rekreacyjnej miasta. Studenci Uniwersytetu Pedagogicznego oraz Uniwersytetu Rolniczego 
największe znaczenie przypisali siłowniom (odpowiednio 29,1\% i 18,4\% wskazań) oraz basenom (odpowiednio 19,3\% i 18,5\%). Z kolei studenci Uniwersytetu Papieskiego Jana Pawła II najczęściej wskazywali boisko do gier zespołowych $(20,3)$ oraz basen i ścieżkę rowerową (po 17,4\% odpowiedzi).

Ryc. 7. Znaczenie obiektów i urządzeń rekreacyjnych w rozwoju funkcji rekreacyjnej miasta w ocenie badanej grupy respondentów

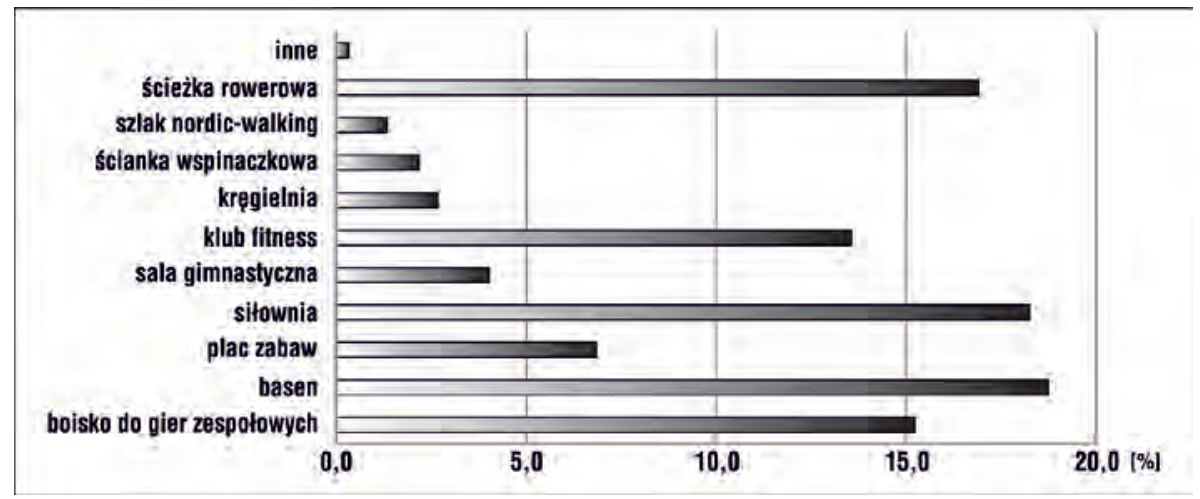

Źródło: opracowanie własne na podstawie przeprowadzonych badań

Tab. 2. Wykorzystanie obiektów i urządzeń rekreacyjno-sportowych w Krakowie przez studentów krakowskich uczelni - rozkład odpowiedzi respondentów na pytanie: „Z jakich obiektów najczęściej korzysta Pan/ Pani podejmując aktywność ruchową?"

\begin{tabular}{|c|c|c|c|c|c|c|c|c|c|c|c|}
\hline \multirow{3}{*}{$\begin{array}{c}\text { Ośrodek } \\
\text { akademicki }\end{array}$} & \multicolumn{11}{|c|}{ Obiekty i urządzenia rekreacyjno-sportowe } \\
\hline & 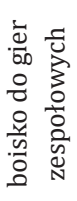 & 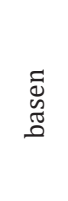 & 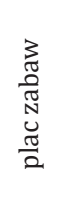 & $\frac{.00}{3}$ & 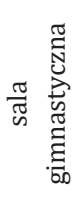 & 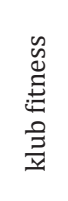 & 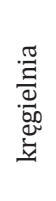 & 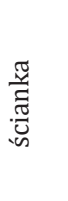 & 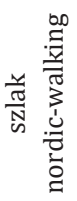 & 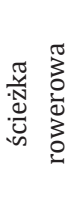 & $\stackrel{\Xi}{\Xi}$ \\
\hline & $\%$ & $\%$ & $\%$ & $\%$ & $\%$ & $\%$ & $\%$ & $\%$ & $\%$ & $\%$ & $\%$ \\
\hline $\begin{array}{c}\text { Uniwersytet } \\
\text { Papieski } \\
\text { w Krakowie }\end{array}$ & 21,7 & 13,0 & 4,3 & 13,0 & 13,0 & 8,7 & 0 & 0 & 0 & 23,9 & 0 \\
\hline $\begin{array}{l}\text { Uniwersytet } \\
\text { Pedagogiczny } \\
\text { w Krakowie }\end{array}$ & 13,3 & 18,7 & 1,1 & 22,8 & 2,2 & 13,9 & 4,4 & 1,7 & 2,2 & 17,8 & 1,1 \\
\hline $\begin{array}{c}\text { Uniwersytet } \\
\text { Rolniczy } \\
\text { w Krakowie }\end{array}$ & 9,5 & 16,2 & 1,1 & 22,3 & 4,5 & 15,1 & 3,9 & 0,6 & 1,1 & 21,8 & 3,9 \\
\hline Ogółem & 12,6 & 17,3 & 1,5 & 21,5 & 4,4 & 13,8 & 3,7 & 1,0 & 1,5 & 20,2 & 2,5 \\
\hline
\end{tabular}

Źródło: opracowanie własne na podstawie przeprowadzonych badań

W tab. 2 oraz na ryc. 8 przedstawiono rozkład odpowiedzi na pytanie „Z jakich obiektów najczęściej korzysta Pan/Pani, podejmując aktywność ruchową?”. 
Respondenci mieli możliwość wskazania maksymalnie trzech odpowiedzi z 11 zaproponowanych. Do najczęściej wykorzystywanych przez badaną grupę studentów obiektów i urządzeń bazy rekreacyjnej Krakowa należą: siłownie (21,5\%), ścieżki rowerowe $(20,2)$, baseny $(17,3 \%)$, oraz kluby fitness $(13,8 \%)$. Znikomą popularnością cieszą się z kolei ścianki wspinaczkowe $(1,0 \%)$, a także szlaki nordic-walking $(1,5 \%)$ i place zabaw $(1,5 \%)$. Podobnie jak w przypadku wcześniej analizowanych odpowiedzi, tak również w tym przypadku widoczne są różnice wskazań studentów badanych uczelni. Studenci kierunku turystyka religijna Uniwersytetu Papieskiego Jana Pawła II w Krakowie, podejmując aktywność ruchową, najczęściej korzystają z ścieżek rowerowych $(23,9 \%$ wskazań) oraz z boisk do gier zespołowych $(21,7 \%)$. Żadna z osób w tej grupie studentów nie wskazała na korzystanie ze ścianki wspinaczkowej, szlaku nordic-walking oraz z kręgielni. Wśród studentów Uniwersytetu Pedagogicznego największą popularnością cieszą się siłownie $(22,8 \%$ wskazań), baseny $(18,7 \%)$, ścieżki rowerowe $(17,8 \%)$ oraz kluby fitness $(13,9 \%)$. Studenci Uniwersytetu Rolniczego, podejmując aktywność ruchową, najczęściej korzystają z siłowni (22,3\% wskazań), ścieżek rowerowych $(21,8 \%)$ oraz basenu (16,2\%) (por. tab. 2 i ryc. 8).

Ryc. 8. Korzystanie z obiektów i urządzeń rekreacyjno-sportowych w Krakowie przez studentów krakowskich uczelni

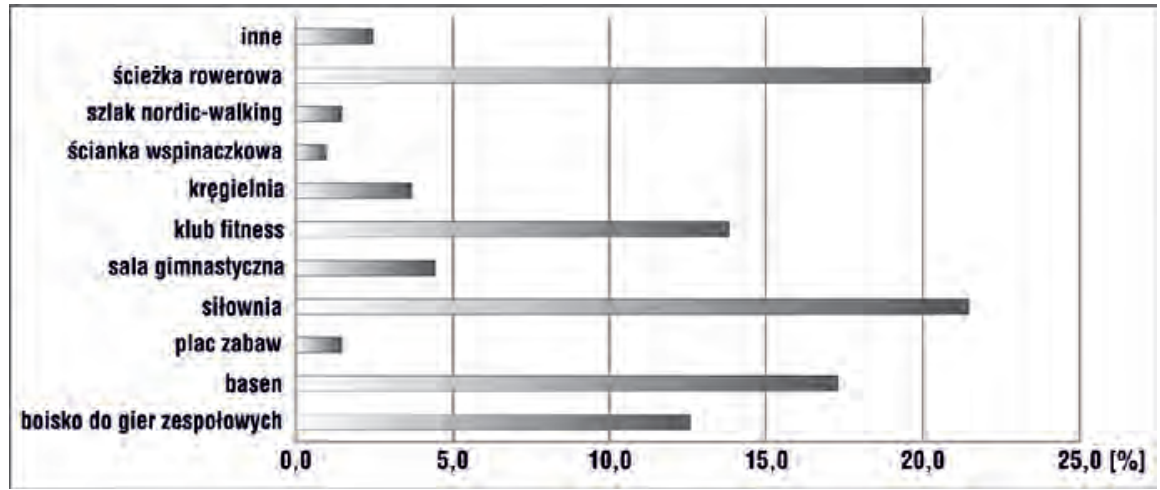

Źródło: opracowanie własne na podstawie przeprowadzonych badań

Ponad 45\% respondentów oceniło funkcję rekreacyjną Krakowa dobrze, a 19,6\% bardzo dobrze. Tylko jedna osoba z badanych na zadane pytanie odpowiedziała krytycznie, zaś $4 \%$ oceniło tę bazę miernie.

\section{ZAKOŃCZENIE}

Aktywny wypoczynek odgrywa rolę nie tylko w kształtowaniu przestrzeni publicznej, wyrażającej się w materialnej obecności zespołu lub założenia sportowo-rekreacyjnego w strukturze miasta, ale wkroczył również do modelu zdrowego życia. Współczesne miasta charakteryzują się bardzo dobrze rozwiniętą funkcją rekreacyjną. W założeniach planistycznych utrzymuje się w dalszym ciągu konieczność istnienia 
w przestrzeni miasta terenów niezabudowanych, zielonych, które mogą być wykorzystywane jako obszary spontanicznej rekreacji. Z drugiej strony w miastach powstają obiekty o wyspecjalizowanej funkcji rekreacyjnej, które są odpowiedzią na zgłaszany popyt mieszkańców miast. W niniejszym opracowaniu założono, że strona podażowa usług turystycznych jest wynikiem mechanizmów wolnorynkowych, w związku z tym skoncentrowano się na stronie popytowej, czyli próbowano odpowiedzieć na pytanie „czy jest realne zapotrzebowanie na usługi rekreacyjne w mieście?”.

Młodzież akademicka tworzy (ze względu na wiek) w miarę homogeniczną grupę społeczno-demograficzną, wyselekcjonowaną i postrzeganą jako awangarda każdego społeczeństwa (Kamińska, 2009). Wydaje się, że badana zbiorowość powinna charakteryzować się zdefiniowanymi potrzebami rekreacyjnymi, prezentując określone postawy oraz zachowania na rynku. Jednocześnie jako środowisko opiniotwórcze wpływa na kształtowanie przeszłych wzorców społecznych w zakresie form i częstotliwości zajęć wolnoczasowych (Gołembski, Hołderna-Mielcarek, Niezgoda, Szmatuła, 2002). Przeprowadzone badania pokazały, że nie tylko czynnik ekonomiczny leży u podstaw braku bądź też niewielkiej aktywności turystycznej studentów, ale przede wszystkim iluzoryczny brak czasu. Analizując współczesne tendencje wykorzystywania wolnego czasu, można sformułować tezę, że jeśli „sport środowiskowy” nie zaoferuje nowej, atrakcyjnej formy oraz dopasowanej do aktualnie panujących trendów powszechnie dostępnej infrastruktury, proces braku zainteresowania dzisiaj aktywną rekreacją młodych ludzi, a w przyszłości dorosłych, będzie się pogłębiał (Ujma-Wąsowicz, 2007).

\section{Literatura \\ References}

Alejziak, W. (2007). Inhibitory aktywności turystycznej. Teoretyczne i metodologiczne aspekty studiów nad ograniczeniami i barierami uczestnictwa w wyjazdach wypoczynkowych, Folia Turistica, 18, 59-87.

Bergier, J. (2012). Aktywność fizyczna społeczeństwa - współczesny problem (przegląd badań), Człowiek i Zdrowie, 6(1).

Czerepniak-Walczak, M. (2007). Od próżniaczenia do zniewolenia - w poszukiwaniu dyskursów czasu wolnego. W: E. Marynowicz-Hetka (red.). Pedagogika społeczna, t. II. Warszawa: PWN.

Delekta, A. (2013). Determinanty aktywności i destynacji turystycznych studentów dużego i małego ośrodka akademickiego. Kraków: Wydawnictwo Naukowe Uniwersytetu Pedagogicznego.

Delekta, A. (2014). Społeczne determinanty aktywności turystycznej studentów krakowskiego ośrodka akademickiego, Humanities and Social Sciences, 19(21), 25-35.

Godek, Ł., Brożyna, M., Śliż, M. (2014). Aktywność turystyczna studentów I roku turystyki i rekreacji w Wydziale Wychowania Fizycznego Uniwersytetu Rzeszowskiego. Turystyka i Rekreacja, 11(2), 82-86.

Gołembski, G., Hołderna-Mielcarek, B., Niezgoda, A., Szmatuła, P. (2002). Model zachowań turystycznych w czasie wolnym polskiej młodzieży studiującej. Problemy turystyki, 1-2, 69-85.

Kamińska, J. (2009). Model wypoczynku wakacyjnego studentów Kielecczyzny i jego determinanty. Handel Wewnętrzny, 11, 76-86.

Latosińska, J., Ludwicka, D. (2010). Aktywność turystyczna młodzieży akademickiej na przykładzie wyższych uczelni w Łodzi. Turyzm, 1, 21-28.

Lubowiecki-Vikuk, A.P., Paczyńska-Jędrycka, M. (2010). Współczesne tendencje $w$ rozwoju form rekreacyjnych i turystycznych. Poznań: Bogucki Wydawnictwo Naukowe. 
Lubowiecki-Vikuk, A.P., Podgórski, Z. (2013). Zachowania i preferencje turystyczne młodzieży akademickiej. W: R. Pawlusiński (red.). Współczesne uwarunkowania i problemy rozwoju turystyki. Kraków: Instytut Geografii i Gospodarki Przestrzennej Uniwersytetu Jagiellońskiego, 149-158.

Maksymiuk, G., (2005). Rozwój terenów rekreacyjnych - wspomaganie czy ograniczenie w przyrodniczej rewitalizacji miast. Teka Komisji Architektury, Urbanistyki i Studiów Krajobrazowych Oddziału Lubelskiego PAN, 1, 149-156.

Młodzi w internecie (2015, 12 grudnia). Dziennik Zachodni. Pozyskano z http://www.dziennikzachodni.pl/artykul/4509763,mlodzi-w-internecie-ponad-polowa-rodzicownie-wie-co-robia-tam-ich-dzieci,1,id,t,sa.html

Mróz, F., Rettinger, R. (2015). Turystyka aktywna a spędzanie czasu wolnego przez studentów kierunku „Turystyka i rekreacja” wybranych szkół wyższych w Małopolsce. W: A. Stasiak, J. Śledzińska, B. Włodarczyk B., (red.). Wczoraj, dziś i jutro turystyki aktywnej i specjalistycznej. Warszawa, 373-386.

Stangel, M., (2013). Kształtowanie współczesnych obszarów miejskich w kontekście zrównoważonego rozwoju. Gliwice: Wydawnictwo Politechniki Śląskiej.

Ujma-Wąsowicz, K. (2007). Otwarte tereny aktywnej rekreacji na obszarach zurbanizowanych. Cele i kierunki rozwoju. Czasopismo Techniczne. Architektura, 104(1A), 169-174.

Young Europeans: A survey among Young people aged between 15 and 30 in the European UnionAnalitycal Report (2007) (2016, 21 stycznia). Flash Eurobarometr, 202. Pozyskano z http:// ec.europa.eu/public_opinion/flash/fl_202_en.pdf

Zaniewska, K. (2012). Kultura czasu wolnego młodzieży akademickiej średniego miasta. Colloquium Wydziału Nauk Humanistycznych i Społecznych, 3, 123-144.

Zielińska, M. (2011). Teoretyczne i metodologiczne problemy badania czasu wolnego - co, jak i po co badać. W: E. Narkiewicz-Niedbalec, M. Zielińska (red.). Młodzież w czasie wolnym. Między przyjemnością a obowiązkami. Toruń: Wydawnictwo Adam Marszałek, 5-6.

Renata Rettinger, doktor, adiunkt w Zakładzie Turystyki i Badań Regionalnych Instytutu Geografii Uniwersytetu Pedagogicznego w Krakowie. Autorka w swoich badaniach koncentruje się na problematyce rozwoju turystyki w regionie karaibskim. W problematyce badawczej przeważają tematy dotyczące wielkości i przestrzennego zróżnicowania zagospodarowania i ruchu turystycznego, a w szczególności kierunki rozwoju turystyki. W opracowaniach przewija się także tematyka enklaw turystycznych jako dominującej formy zagospodarowania turystycznego na Karaibach w kontekście rozwoju zrównoważonego i turystyki pro-poor.

Renata Rettinger, Ph.D., an assistant professor at the Department of Tourism and Regional Research of the Institute of Geography at the Pedagogical University of Cracow. In her research, the author concentrates on the problems of tourism development in the Caribbean region. Her research is mostly concerned with issues of the size and spatial differentiation of tourist infrastructure and tourism volume itself, alongside the directions of tourism development. The research topics also include the issue of tourist enclaves as a dominating form of tourist infrastructure in Caribbean in the light of sustainable development and pro-poor tourism.

Franciszek Mróz, doktor, geograf społeczno-ekonomiczny, pracownik naukowo-dydaktyczny (adiunkt) w Zakładzie Turystyki i Badań Regionalnych Instytutu Geografii Uniwersytetu Pedagogicznego w Krakowie. Wykładowca w Uniwersytecie Papieskim Jana Pawła II w Krakowie. Tytuł doktora nauk o Ziemi w zakresie geografii otrzymał w 2006 roku na podstawie rozprawy doktorskiej nt. genezy i typologii sanktuariów Pańskich w Polsce, przygotowanej pod kierunkiem prof. dr. hab. Antoniego Jackowskiego w Instytucie Geografii i Gospodarki Przestrzennej UJ. Konsultor w Radzie ds. Migracji, Turystyki i Pielgrzymek Konferencji Episkopatu Polski. Członek Archicofradía Universal del Apóstol Santiago. Instruktor Krajoznawstwa Polski. Członek zespołu konsultacyjnego ds. przygotowania planu działań na rzecz rozwoju turystyki religijnej w Krakowie do roku 2020 powołanego przez prezydenta miasta Krakowa. Obecnie jego zainteresowania badawcze koncentrują się m.in. wokół zagadnień związanych z pielgrzymowaniem, turystyką religijną i turystyką 
kulturową w Polsce, genezą i funkcjonowaniem ośrodków pielgrzymkowych w Europie, a także europejskimi szlakami kulturowymi, ze szczególnym uwzględnieniem Camino de Santiago - Drogi św. Jakuba. Jest autorem ponad 90 publikacji naukowych i ponad 40 publikacji popularnonaukowych z tego zakresu, a także redaktorem 11 prac zbiorowych.

Franciszek Mróz, Ph.D., an assistant professor at the Department of Tourism and Regional Research of the Institute of Geography at the Pedagogical University of Cracow. Lecturer at the Pontifical University of John Paul II in Cracow. In 2006 he received his Ph.D. in Earth Science in the fiels of geography based on a doctoral dissertation entitled Origins and Typology of Sanctuaries in Poland, written under the supervision of Professor Antoni Jackowski, Ph.D., of the Institute of Geography and Spatial Management at the Jagiellonian University. He is a consultant in the Migration, Tourism and Pilgrimage Council of the Polish Episcopal Conference, member of Archicofradía Universal del Apóstol Santiago, instructor of Polish cultural and regional studies. He is also a member of the consulting team for the preparation of the Action Plan for the development of religious tourism in Cracow until 2020, nominated by the Mayor of Cracow. His present research interests are concentrated on, for example, issues related to pilgrimages, religious and cultural tourism in Poland, origins and functioning of pilgrimage centres in Europe, and European cultural routes, especially Camino de Santiago - the Way of St. James. He is the author of more than 90 publications and more than 40 popular science publications in this field, as well as an editor of 11 collaborative publications.

\section{Adres/Address:}

Uniwersytet Pedagogiczny w Krakowie Instytut Geografii

Zakład Turystyki i Badań Regionalnych ul. Podchorążych 2, 30-084 Kraków, Polska

e-mail: rettinger@onet.eu (Renata Rettinger)

e-mail: fmroz@up.krakow.pl (Franciszek Mróz) 